\title{
Studies on the male sterility of Satsuma orange (Citrus unshiu MARC.)
}

\author{
Effect of temperature on the recovery of pollen fertility \\ concerning the metabolism of carbohydrates \\ and enzyme activities in anther
}

Hsu-Jen Yang and Shoichi Nakagawa

College of Agriculture, University of Osaka Prefecture, Sakai, Osaka

\begin{abstract}
Summary
Pollen fertility of Satsuma orange could be increased about 14 to $23 \%$ by the temperature treatments (at $15^{\circ} \mathrm{C}$ and $20^{\circ} \mathrm{C}$ ) as compared with the outdoor control. At $25^{\circ} \mathrm{C}$ temperature treatment, the increase of pollen fertility was a little higher than the outdoor control, but the flowers were comparatively smaller in size and feeble which dropped off within 2 or 3 weeks after anthesis. Therefore, it may be considered that the favorable minimum temperature during the growth and development of flower buds is $15 \sim 20^{\circ} \mathrm{C}$, deliberating on the increase of pollen fertility and the development of flower buds.

The increase of pollen fertility caused by the temperature treatment would be attributed to the recovery of some of the vacuous starveling microspores at the vacuole enlarging stage and the starch accumulation in microspore at the vacuole disappearing stage.

These phenomena indicate the following: 1)

amylase and maltase in anther and activity of starch synthesizing enzyme system in microspore were increased by the high temperature treatments. 2) These high activities of the enzyme might decompose much more starch which reserved in anther walls and supplied rich nutrient to microspore. Furthermore, it might also release much more energy through the glycolytic pathway in anther. 3) The vacuous starveling microspores might have utilized the rich energy and absorbed the nutrient from periphery of the anther sac and excluded the large vacuole from the cytoplasm in microspore. 4) As a result, a great number of microspores recovered from the critical vacuole enlarging stage during the pollen develoment and deposited starch in the cytoplasm at the vacuole disappearing stage. 5) Consequently, those recovering microspores proceeded to the next growth cycle, became viable pollen grains and increased the pollen fertility at anthesis.
\end{abstract} Enzyme activities, such as hexokinase, invertase,

\section{Introduction}

Cytological and histological studies on the pollen sterility of Citrus plants have been carried out by many workers, concerning the influence of low- and high-temperatures $(4,10,16,18,30)$ YANG et al. ${ }^{(30)}$ also described that the pollen fertility could be increased and the abnormal behavior of tapetum could be recovered partially by the temperature treatment (above $20^{\circ} \mathrm{C}$ ) during the pollen development. However, the mechanism of its physiological bases is still obscure.

Nakamura ${ }^{(18)}$ stated that the nutrient supply to the starved microspores was decreased at vacuole stage and the reservation of starch in microspore after the vacuole disappearing stage was disturbed by the influence of low temperature. It is well known that under low temperature conditions the microspores fail to reserve starch at the vacuole disappearing stage and the starch content decreases markedly in anther wall at the initial stage of its development ${ }^{(29)}$

Received for publication January 28, 1970 
These phenomena may be related to the activities of enzymes, such as amylase, invertase and hexokinase.

The experiment reported herein was carried out to depict the influence of temperatures on the pollen sterility concerning the metabolism of carbohydrates and enzyme activities in anther at the vacuole stage of microspore and to make sure the mechanism of pollen abortion in Satsuma orange.

\section{Materials and Methods}

Materials used for this study were 5 6 years old Satsuma orange trees (Citrus unshiu MARc.), which were planted individually in $60 \mathrm{~cm}$ diameter unglazed pots containing loamy soil. Each plot consisted of nine plants. Vinyl chambers $(2 \times 2 \times 1.8 \mathrm{~m})$ were made in the glasshouse for the temperature treatments. Air temperatures for warming within the chambers were controlled electrically by using the lead heating cells. Furthermore, only the minimum temperatures were checked throughout the experiments in each chamber at $10,15,20$ and $25^{\circ} \mathrm{C}$, respectively. Temperature treatments were carried out from mid January to early Spring during 1968-1969.

For cytological studies fresh sample of flower buds were collected at $1 \sim 2$ days intervals. Microspores and pollen grains were stained with aceto-carmine, and their sizes were measured at various developmental stages by micrometer. During the course of development of pollen grains, iodine potassium iodine solution was used for the observation of starch in microspores and pollen grains.

Analysis of sugars in anther was done with the thin layer chromatography (TLC). The development was carried out twice by dimentional ascending manner in the solvent mixture of ethyl acetate/iso-propylalcohol $(70: 30, \mathrm{v} / \mathrm{v})$ and ethyl acetate/iso-propylalcohol/water (52: $36: 12, \mathrm{v} / \mathrm{v})$. Sulfate anisaldehyde was used as color reagent.

The contents of reducing sugar, non-reducing sugar and starch in anther at various stages were estimated according to the method of Somogyi ${ }^{(26)}$.

Activity of starch synthesizing enzyme system in microspore: Fresh samples of anther at the vacuole disappearing stage of microspore were collected and the method of histo-chemical test was used ${ }^{(13,22,27)}$. All these anthers cut in two were incubated in the medium with glucose-1-phosphate. The number of microspore with starch were investigated by using the smear method with iodine potassium iodine solution. Preliminary works indicated that optimum condition for the activity of starch synthesizing enzyme system in microspore at the vacuole disappearing stage was at $37^{\circ} \mathrm{C}$ and sodium acetate buffer $\mathrm{pH} 5.0$ for 24 hours.

Activities of various enzymes in anther: The anther at the vacuole enlarging stage were collected and stored in refrigerator at $-20^{\circ} \mathrm{C}$ until the extractions were made. Enzymes (amylase, maltase, invertase and hexokinase) were extracted according to the method of Katsumata et $a l^{(11,12,13)}$.

Amylase activity: Amylase activity was expressed by the determination of the dextrinizing $\operatorname{activity}^{(1)}$ and of the saccharogenic activity ${ }^{(21)}$. The optimum condition for dextrinization was at $40^{\circ} \mathrm{C}$ and sodium acetate buffer $\mathrm{pH} 6.5$, and for saccharogen was at $40^{\circ} \mathrm{C}$ and phosphate buffer $\mathrm{pH} 6.0 \sim 6.5$. 
Invertase and maltase activities: The enzyme activity was determined following the methods of Somogyi ${ }^{(26)}-\mathrm{NeLSON}^{(19)}$. The optimum condition of maltase was at $40^{\circ} \mathrm{C}$ and sodium acetate

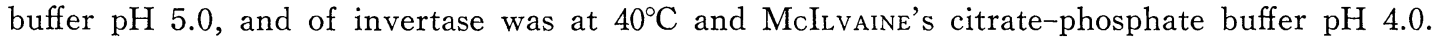

Hexokinase activity: Hexokinase activity was expressed by the determination of the phosphorylations of glucose and fructose. The phosphorylation of glucose was estimated by the methods of SomOGYI ${ }^{(26)}-\mathrm{NeLSON}^{(19)}$, and the phosphorylation of fructose was determined by the method of $\mathrm{RoE}^{(23)}$. The optimum condition for hexokinase activity was at $37^{\circ} \mathrm{C}$ and $\mathrm{Tris}-\mathrm{HCl}$ buffer $\mathrm{pH} 7.5$.

\section{Results}

\section{Effect of temperature on the growth and development of flower buds and pollen grains :}

Preliminary experiments revealed that even at any time of dormancy in winter the Satsuma orange trees which were kept under high temperature conditions showed flower formation
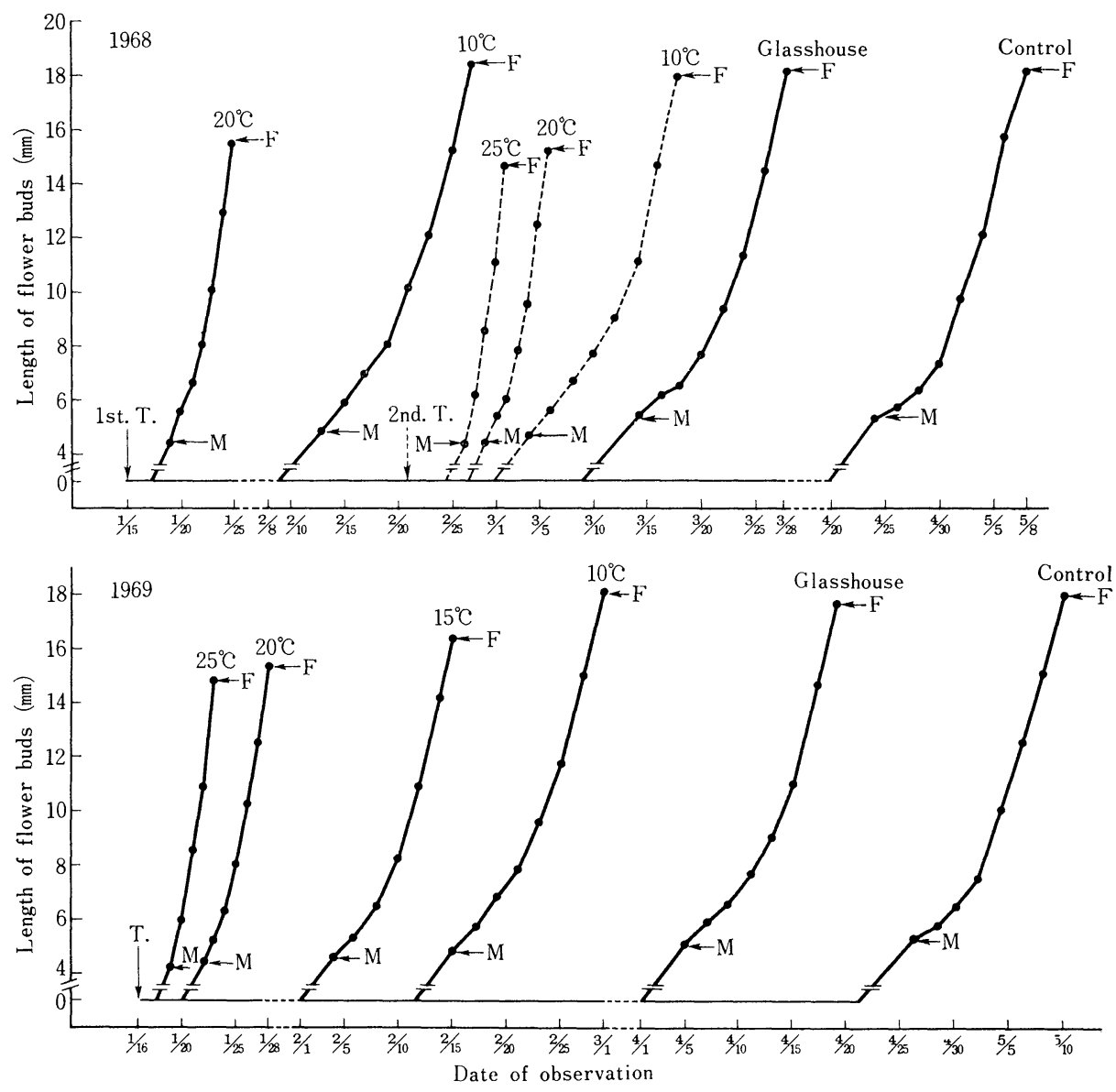

Fig. 1. Effect of temperature on the growth of flower buds and flowering date.

$\mathrm{F}$ : flowering (Stage VIII). M : young microspore (Stage I).

1 st T. (-) : first treatment, 2 nd T. ( .....) : second treatment.

$\mathrm{T}$ : treatment 
Table 1. Effect of temperature on the flowering habit in Satsuma orange.

\begin{tabular}{|c|c|c|c|c|c|c|c|c|c|c|}
\hline \multirow{2}{*}{\multicolumn{2}{|c|}{ Treatments }} & \multirow{2}{*}{$\begin{array}{l}\text { Date of } \\
\text { treatment }\end{array}$} & \multirow{2}{*}{$\begin{array}{l}\text { Date of } \\
\text { changing the } \\
\text { treatment }\end{array}$} & \multicolumn{3}{|c|}{$\begin{array}{l}\text { Average temperature from } \\
\text { Stage I to Stage VIII } 1)\end{array}$} & \multirow{2}{*}{$\begin{array}{l}\text { Date of } \\
\text { bloom }\end{array}$} & \multirow{2}{*}{$\begin{array}{c}\text { Length } \\
\text { of } \\
\text { pistil } \\
\text { mm }\end{array}$} & \multirow{2}{*}{$\begin{array}{c}\text { Length } \\
\text { of } \\
\text { stamen } \\
\mathrm{mm}\end{array}$} & \multirow{2}{*}{$\begin{array}{c}\left.\mathrm{LP}-\mathrm{LS}^{2}\right) \\
\mathrm{mm}\end{array}$} \\
\hline & & & & mum & mum & & & & & \\
\hline \multirow[t]{3}{*}{ Control } & -1 & Jan. 15,68 & - & $22.3^{\circ} \mathrm{C}$ & $10.4^{\circ} \mathrm{C}$ & $16.4^{\circ} \mathrm{C}$ & May $8, ' 68$ & 16.4 & 12.1 & 4.3 \\
\hline & -2 & Feb. $21,{ }^{\prime} 68$ & - & 22.3 & 10.4 & 16.4 & "I & 16.1 & 12.0 & 4.1 \\
\hline & -3 & Jan. $16,{ }^{\prime} 69$ & - & 25.4 & 9.7 & 17.6 & May $10, ' 69$ & 16.1 & 12.0 & 4.1 \\
\hline \multirow[t]{3}{*}{ Glasshouse } & -1 & Jan. $15,{ }^{\prime} 68 \mid$ & - & 28.0 & 10.6 & 19.3 & Mar. 28, '68 & 15.2 & 11.7 & 3.5 \\
\hline & -2 & Feb. $21,{ }^{\prime} 68$ & - & 28.0 & 10.6 & 19.3 & 11 & 15.3 & 11.7 & 3.6 \\
\hline & -3 & Jan. $16,{ }^{\prime} 69$ & - & 27.5 & 9.8 & 18.7 & Apr. 19, '69 & 15.6 & 12.0 & 3.6 \\
\hline \multirow[t]{3}{*}{$10^{\circ} \mathrm{C}$} & -1 & Jan. $15,{ }^{\prime} 68$ & - & 25.8 & 10.0 & 17.9 & Feb. 27, '68 & 16.1 & 12.2 & 3.9 \\
\hline & -2 & Feb. $21,{ }^{\prime} 68$ & - & 25.6 & 10.0 & 17.8 & Mar. 18, '68 & 16.1 & 12.1 & 4.0 \\
\hline & -3 & Jan. $16,{ }^{\prime} 69$ & - & 26.1 & 10.0 & 18.1 & Mar. 1, '69 & 15.9 & 12.1 & 3.8 \\
\hline $15^{\circ} \mathrm{C}$ & -1 & Jan. $16,{ }^{\prime} 69$ & - & 26.5 & 15.0 & 20.8 & Feb. 15, '69 & 13.5 & 10.8 & 2.7 \\
\hline \multirow[t]{3}{*}{$20^{\circ} \mathrm{C}$} & -1 & Jan. $15, ' 68$ & - & 31.4 & 20.0 & 25.7 & Jan. 25, '68 & 13.1 & 11.6 & 1.5 \\
\hline & -2 & Feb. 21, '68 & 一 & 31.4 & 19.7 & 25.6 & Mar. 6,'68 & 12.8 & 11.4 & 1.4 \\
\hline & -3 & Jan. $16,{ }^{\prime} 69$ & - & 32.2 & 20.0 & 26.1 & Jan. 28, '69 & 12.9 & 11.4 & 1.5 \\
\hline \multirow[t]{2}{*}{$25^{\circ} \mathrm{C}$} & -1 & Feb. $21,{ }^{\prime} 68$ & - & 32.3 & 24.6 & 28.5 & Mar. 2,' 68 & 11.7 & 10.6 & 1.1 \\
\hline & -2 & Jan. $16,{ }^{\prime} 69$ & - & 33.0 & 24.9 & 29.0 & Jan. $23, ' 69$ & 11.8 & 10.9 & 0.9 \\
\hline \multicolumn{2}{|c|}{$20^{\circ} \mathrm{C} \underset{\text { Glasshouse }^{3)}}{\stackrel{\mathrm{I}}{\longrightarrow}}$} & Jan. $15,{ }^{\prime} 68$ & Feb. 5, '68 & 19.7 & 1.2 & 10.5 & Mar. $9, ' 68$ & 14.8 & 11.5 & 3.3 \\
\hline \multicolumn{2}{|c|}{$20^{\circ} \mathrm{C} \underset{\text { Glasshouse }}{\stackrel{\mathrm{IV}}{\longrightarrow}}$} & "l & "l & 17.2 & 0.5 & 8.9 & Feb. 22,' 68 & 13.0 & 10.5 & 2.5 \\
\hline \multicolumn{2}{|c|}{$\begin{array}{l}\text { Glasshouse } \\
\left.\qquad \stackrel{\mathrm{I}}{\longrightarrow} 20^{\circ} \mathrm{C}^{4}\right)\end{array}$} & "1 & Mar. 26, '68 & 31.9 & 21.0 & 26.5 & Apr. 3,' 68 & 14.6 & 11.5 & 3.1 \\
\hline \multicolumn{2}{|c|}{$\begin{array}{l}\text { Glasshouse } \\
\qquad \stackrel{\mathrm{IV}}{\longrightarrow} 20^{\circ} \mathrm{C}^{4)}\end{array}$} & "I & 11 & 32.1 & 21.1 & 26.6 & Apr. 1, '68 & 14.0 & 10.9 & 3.1 \\
\hline
\end{tabular}

1) I, II, ... Showing the respective stage of pollen grains development.

I : Soon after the liberation of microspores from the wall of pollen tetrads.

II : Vacuole appearing stage of microspore.

III : Vacuole enlarging stage of microspore.

IV : Vacuole disappearing stage of microspore.

$\mathrm{V}$ : Pollen mitosis stage.

VI : Young pollen grain stage.

VII : Mature pollen grain stage.

VIII : Blooming stage.

2) Length of pistil-Length of stamen.

3) When the plants having the flower buds either at Stage I or Stage IV grown under $20^{\circ} \mathrm{C}$ were transferred into the glasshouse without heat system.

4) When the plants possessing the flower buds either at Stage I or Stage IV grown under glasshouse without heat system were transferred in to $20^{\circ} \mathrm{C}$ minimum temperature chamber.

within a few days and accelerated blooming time. As shown in Fig. 1, the plants treated with $20^{\circ} \mathrm{C}$ or $25^{\circ} \mathrm{C}$ in January and February bloomed within 2 weeks after treatments. The growth of flower buds under high temperature conditions was more rapid than that under low temperature conditions. To explain further, after the treatments it bloomed 7 to 10 days at $25^{\circ} \mathrm{C}, 10$ to 14 days at $20^{\circ} \mathrm{C}, 30$ days at $15^{\circ} \mathrm{C}$ and 43 to 44 days at $10^{\circ} \mathrm{C}$.

The ultimate size of flower buds under high temperature was smaller than those under low temperature and the control. The flowers were smaller in size, closing stigma and anthers (Table 1, and Fig. 2) under high temperature conditions $\left(25^{\circ} \mathrm{C}\right.$ and $\left.20^{\circ} \mathrm{C}\right)$. Those appeared feeble dropped off within 2 or 3 weeks after the anthesis at $25^{\circ} \mathrm{C}$ treatment. On the contrary, the flowers under low temperature $\left(10^{\circ} \mathrm{C}\right)$ were as large in size as that in the case of control, and the stigma and anthers showed a tendency to remain at a long distance. Detailed 
observations of the development of pollen grains under various temperature treatments were shown in Fig. 3. It took long time for the maturity of the pollen grains in low temperature in comparison to high temperature, namely, the number of days from the vacuole appearing stage (Stage II) to the vacuole disappearing stage (Stage IV), the most important period during the pollen development, was 6 days at $10^{\circ} \mathrm{C}$ as well as in the control, 4 days at $15^{\circ} \mathrm{C}$, 2 days at $20^{\circ} \mathrm{C}$ and 1.5 days at $25^{\circ} \mathrm{C}$. There were no marked differences in the size of pollen grains at anthesis of all the treatments.

\section{Effect of temperature on the pollen sterility :}

Variation of pollen sterility in Satsuma orange occurred under various temperature treatments is shown in Table 2. The pollen sterilities at $20^{\circ} \mathrm{C}$ and $15^{\circ} \mathrm{C}$ decreased about 23 and $14 \%$ respectively, when compared with the outdoor control, whereas at $10^{\circ} \mathrm{C}$ and $25^{\circ} \mathrm{C}$ decreased only 4 and $6 \%$ respectively than the control.

When the plants having the flower buds either at Stage I or Stage IV grown under $20^{\circ} \mathrm{C}$ were transferred into the glasshouse without heat system (hereafter referred to as $20^{\circ} \mathrm{C}$ $\stackrel{\text { I or IV }}{\longrightarrow}$ glasshouse) on Feb. 5, 1968, the former flower buds (Stage I) showed very high pollen sterility, i.e., 90\%, and the latter ones (Stage IV) showed as low sterility as that at $10^{\circ} \mathrm{C}$, i.e., 78\%. Furthermore, when the plants possessing the flower buds either at Stage I or Stage IV grown under glasshouse without heat system were transferred into the $20^{\circ} \mathrm{C}-$
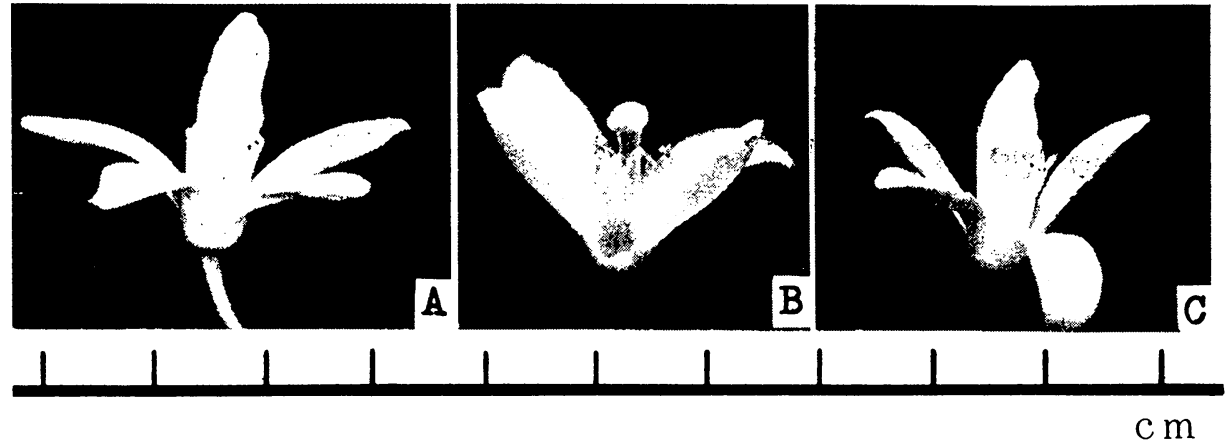

Fig. 2. Photographs showing the flower styles in Satsuma orange under different temperature conditions.

A : Control, $\mathrm{B}: 15^{\circ} \mathrm{C}$, and $\mathrm{C}: 20^{\circ} \mathrm{C}$.

Different lengths between stigma and anthers are notable.

minimum temperature chamber (hereafter referred to as glasshouse $\stackrel{\mathrm{I} \text { or } \mathrm{IV}}{\longrightarrow} 20^{\circ} \mathrm{C}$ ) on March 26 , 1968, the flower buds (Stage I) showed a little decrease in their pollen sterility about $7 \%$ and the flower buds (Stage IV) showed only about 3\% decrease as compared with the control of the glasshouse. The decrease in pollen sterility at $20^{\circ} \mathrm{C}$ and $15^{\circ} \mathrm{C}$ were associated with the decrease in the number of large and medium sized abortive pollen grains, which, indeed, affected the sterility.

Furthermore, the increase in pollen sterility at $20^{\circ} \mathrm{C} \stackrel{\mathrm{I}}{\longrightarrow}$ glasshouse was also associated with the increase in the number of medium sized abortive pollen grains. It may be said that the the pollen grains ceased their growth at Stage III (the critical period of the degeneration of pollen grain) under unfavorable low temperature conditions. A large number of small sized pollen grains at $25^{\circ} \mathrm{C}$ were due to the abnormality of meiotic division and sporads at pollen tetrads (Table 3). There were no marked differences in the number of abnormal pollen grains 


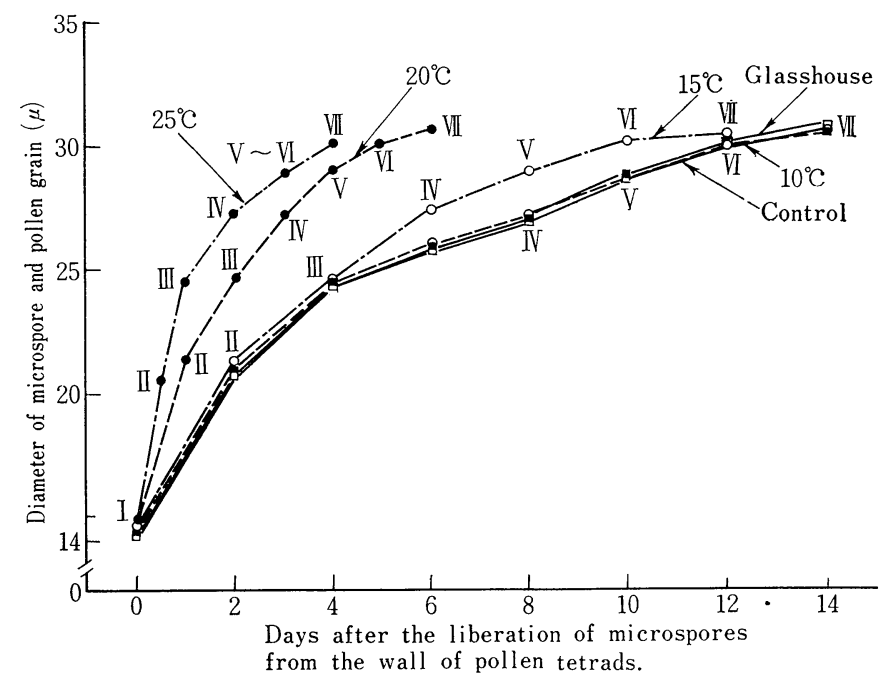

Fig. 3. Effect of temperature on the development of pollen grains.

Table 2. Effect of temperature on the pollen sterility in Satsuma orange.

\begin{tabular}{|c|c|c|c|c|c|c|c|}
\hline \multirow[b]{2}{*}{ Treatments } & \multirow{2}{*}{$\begin{array}{l}\text { No. of } \\
\text { pollen } \\
\text { grains } \\
\text { observed }\end{array}$} & \multicolumn{4}{|c|}{ Number of abortive pollen grains } & \multirow{2}{*}{$\begin{array}{l}\text { Pollen } \\
\text { sterility } \\
(\%)\end{array}$} & \multirow{2}{*}{$\begin{array}{l}\text { Pollen } \\
\text { fertility } \\
(\%)\end{array}$} \\
\hline & & $\begin{array}{c}\text { Large } \\
(>27.5 \mu)\end{array}$ & $\begin{array}{c}\text { Medium } \\
(27.5- \\
22.5 \mu)\end{array}$ & $\left|\begin{array}{c}\text { Small } \\
(22.5 \mu>)\end{array}\right|$ & $\begin{array}{c}\text { Total } \\
\text { number }\end{array}$ & & \\
\hline Control & 1000 & 284 & 498 & 52 & 834 & 83.4 & 16.6 \\
\hline Glasshouse & 1000 & 260 & 470 & 44 & 774 & 77.4 & 22.6 \\
\hline $10^{\circ} \mathrm{C}$ & 1000 & 256 & 488 & 50 & 794 & 79.4 & 20.6 \\
\hline $15^{\circ} \mathrm{C}$ & 1000 & 230 & 411 & 49 & 690 & 69.0 & 31.0 \\
\hline $20^{\circ} \mathrm{C}$ & 1000 & 197 & 352 & 55 & 604 & 60.4 & 39.6 \\
\hline $25^{\circ} \mathrm{C}$ & 1000 & 260 & 415 & 102 & 777 & 77.7 & 22.3 \\
\hline $20^{\circ} \mathrm{C} \stackrel{\mathrm{I}}{\longrightarrow}$ Glasshouse & 1000 & 162 & 693 & 53 & 908 & 90.8 & 9.2 \\
\hline $20^{\circ} \mathrm{C} \stackrel{\mathrm{IV}}{\longrightarrow}$ Glasshouse & 1000 & 267 & 468 & 50 & 785 & 78.5 & 21.5 \\
\hline Glasshouse $\stackrel{\mathrm{I}}{\longrightarrow} 20^{\circ} \mathrm{C}$ & 1000 & 221 & 438 & 43 & 702 & 70.2 & 29.8 \\
\hline Glasshouse $\stackrel{\mathrm{IV}}{\longrightarrow} 20^{\circ} \mathrm{C}$ & 1000 & 241 & 462 & 45 & 748 & 74.8 & 25.2 \\
\hline
\end{tabular}

Table 3. Effect of temperature on the abnormalities in meiotic division and at pollen tetrads stage.

\begin{tabular}{|c|c|c|c|c|c|c|c|c|c|c|}
\hline & Control & $\begin{array}{l}\text { Glass- } \\
\text { house }\end{array}$ & $10^{\circ} \mathrm{C}$ & $15^{\circ} \mathrm{C}$ & $20^{\circ} \mathrm{C}$ & $25^{\circ} \mathrm{C}$ & $\begin{array}{c}20^{\circ} \mathrm{C} \\
\downarrow^{\mathrm{I}} \\
\text { Glass- } \\
\text { house }\end{array}$ & $\begin{array}{c}20^{\circ} \mathrm{C} \\
\downarrow \mathrm{IV} \\
\text { Glass- } \\
\text { house }\end{array}$ & $\begin{array}{c}\text { Glass- } \\
\text { house } \\
\text { I I } \\
20^{\circ} \mathrm{C}\end{array}$ & $\begin{array}{c}\text { Glass- } \\
\text { house } \\
\mid \mathrm{IV} \\
20^{\circ} \mathrm{C}\end{array}$ \\
\hline $\begin{array}{l}\text { No. of PMCs or } \\
\text { sporads observed }\end{array}$ & 500 & 500 & 500 & 500 & 500 & 500 & 500 & 500 & 500 & 500 \\
\hline $\begin{array}{l}\text { Abnormality in meiotic } \\
\text { division in PMCs }(\%)\end{array}$ & 4.2 & 4.0 & 3.8 & 3.6 & 4. 0 & 4.7 & 3.9 & 4.0 & 3.8 & 4.0 \\
\hline $\begin{array}{l}\text { Abnormality at pollen- } \\
\text { tetrads stage }(\%)\end{array}$ & 4.5 & 4.6 & 4.5 & 4.4 & 5.1 & 7.6 & 4.8 & 4.7 & 4.5 & 4.8 \\
\hline
\end{tabular}


Table 4. Effect of temperature on the frequency of various types of pollen grains in Satsuma orange.

\begin{tabular}{|c|c|c|c|c|c|c|}
\hline \multirow[b]{2}{*}{ Treatments } & \multirow{2}{*}{$\begin{array}{c}\text { No. of } \\
\text { pollen } \\
\text { grains } \\
\text { observed }\end{array}$} & \multirow{2}{*}{$\begin{array}{l}\text { No. of } \\
\text { normal } \\
\text { pollen } \\
\text { grains }\end{array}$} & \multicolumn{4}{|c|}{ No. of abnormal pollen grains } \\
\hline & & & Empty & $\begin{array}{c}\text { With one and } \\
\text { more than } \\
\text { two nuclei }\end{array}$ & $\begin{array}{l}\text { With the } \\
\text { disin tegration } \\
\text { of cytoplasm }\end{array}$ & $\begin{array}{c}\text { Total } \\
\text { number }\end{array}$ \\
\hline Control & 1000 & 166 & 593 & 77 & 164 & 834 \\
\hline Glasshouse & 1000 & 226 & 527 & 80 & 167 & 774 \\
\hline $10^{\circ} \mathrm{C}$ & 1000 & 206 & 541 & 85 & 168 & 794 \\
\hline $15^{\circ} \mathrm{C}$ & 1000 & 310 & 455 & 79 & 156 & 690 \\
\hline $20^{\circ} \mathrm{C}$ & 1000 & 396 & 395 & 59 & 150 & 604 \\
\hline $25^{\circ} \mathrm{C}$ & 1000 & 223 & 532 & 73 & 172 & 777 \\
\hline $20^{\circ} \mathrm{C} \stackrel{\mathrm{I}}{\longrightarrow}$ Glasshouse & 1000 & 92 & 723 & 54 & 131 & 908 \\
\hline $20^{\circ} \mathrm{C} \stackrel{\mathrm{IV}}{\longrightarrow}$ Glasshouse & 1000 & 215 & 519 & 79 & 187 & 785 \\
\hline Glasshouse $\stackrel{\mathrm{I}}{\longrightarrow} 20^{\circ} \mathrm{C}$ & 1000 & 298 & 451 & 73 & 178 & 702 \\
\hline Glasshouse $\stackrel{I V}{\longrightarrow} 20^{\circ} \mathrm{C}$ & 1000 & 252 & 508 & 77 & 163 & 748 \\
\hline
\end{tabular}

in all the temperature treatment, except at $20^{\circ} \mathrm{C} \stackrel{\mathrm{I}}{\rightarrow}$ glasshouse. It can be emphasized that the sterility of the pollen grains depends on the variation of the number of empty pollen grains at the various temperature conditions during the flower bud development (Table 4).

\section{Effect of temperature on the contents of carbohydrates in anther :}

Carbohydrates, such as starch and sugars, in anther at the vacuole enlarging stage of microspore (Stage III) at various temperature treaiments were determined (Fig. 4). The amount of starch content in anther was the least at $25^{\circ} \mathrm{C}$ and it gradually increased with the decrease in the temperature under all treatments. The amount of total sugars and nonreducing sugar in anther above $15^{\circ} \mathrm{C}$ temperature treatments were comparatively higher than that at $10^{\circ} \mathrm{C}$ and that of outdoor control.

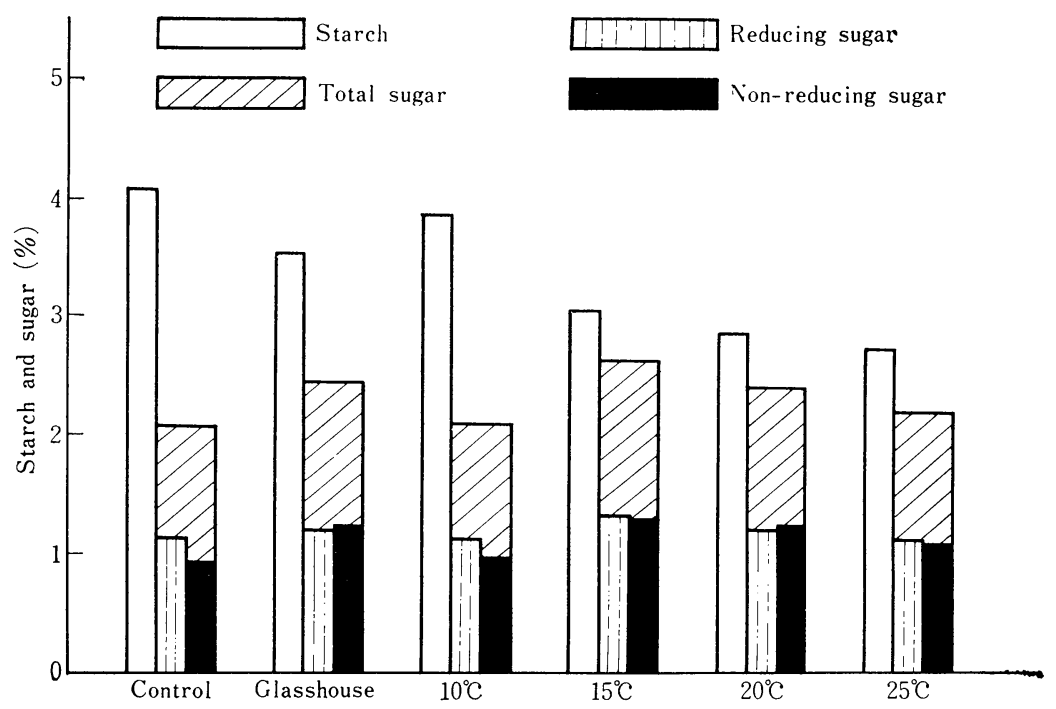

Fig. 4. Effect of temperature on the contents of sugar and starch in anther at the vacuole enlarging stage of microspore. 
In Fig. 5, the effects of temperature on the changes in starch and sugar contents in anther at various stages of pollen development under $20^{\circ} \mathrm{C}$ temperature condition and outdoor control were graphically demonstrated. Total sugar contents in anther both under $20^{\circ} \mathrm{C}$ and outdoors increased at the early stages of pollen development from Stage I to III, remained constant from stage IV to VII and increased again. The sugar contens at $20^{\circ} \mathrm{C}$, however, were always higher than the outdoor control throughout all stages of pollen development. On the contrary, the fluctuation of starch contents in anther occurred during the pollen development both under $20^{\circ} \mathrm{C}$ and outdoor control as shown in Fig. 4-D. It decreased at the early stages of pollen development, followed by a little increase and sharp drop. The fluctuation under $20^{\circ} \mathrm{C}$ was wider than the outdoor control throughout the growing stages of microspore development.

Fig. 5. Changes in sugar and starch contents $\rightarrow$ in anther at various stages of pollen development as affected by the temperature treatment $\left(20^{\circ} \mathrm{C}\right)$.
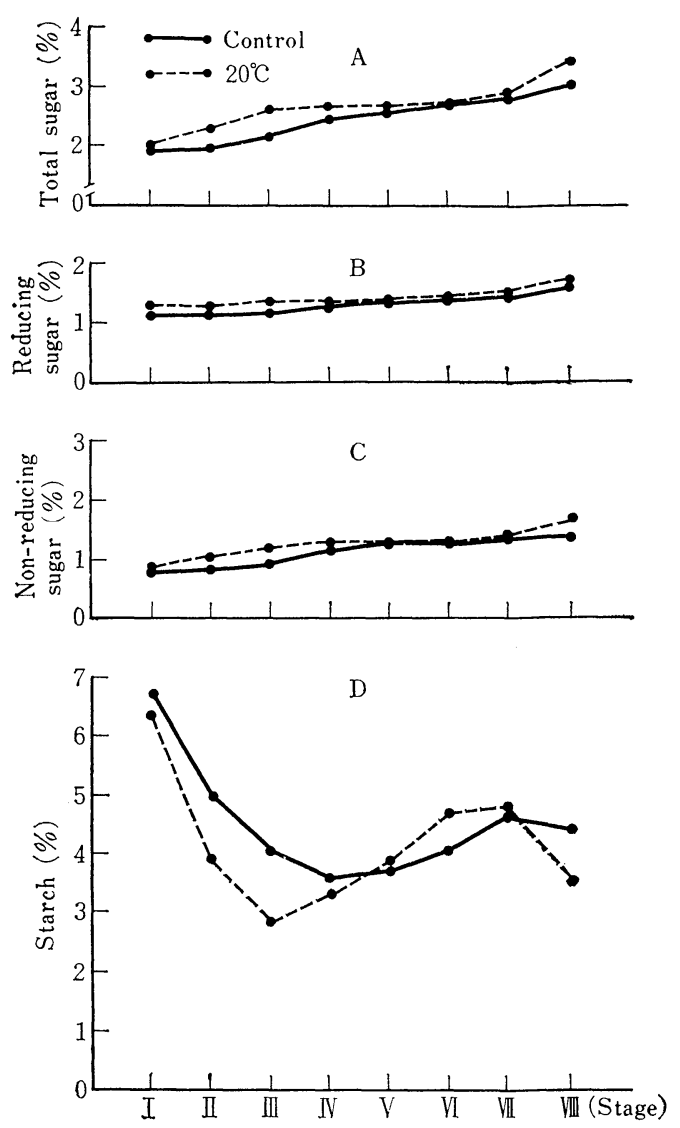

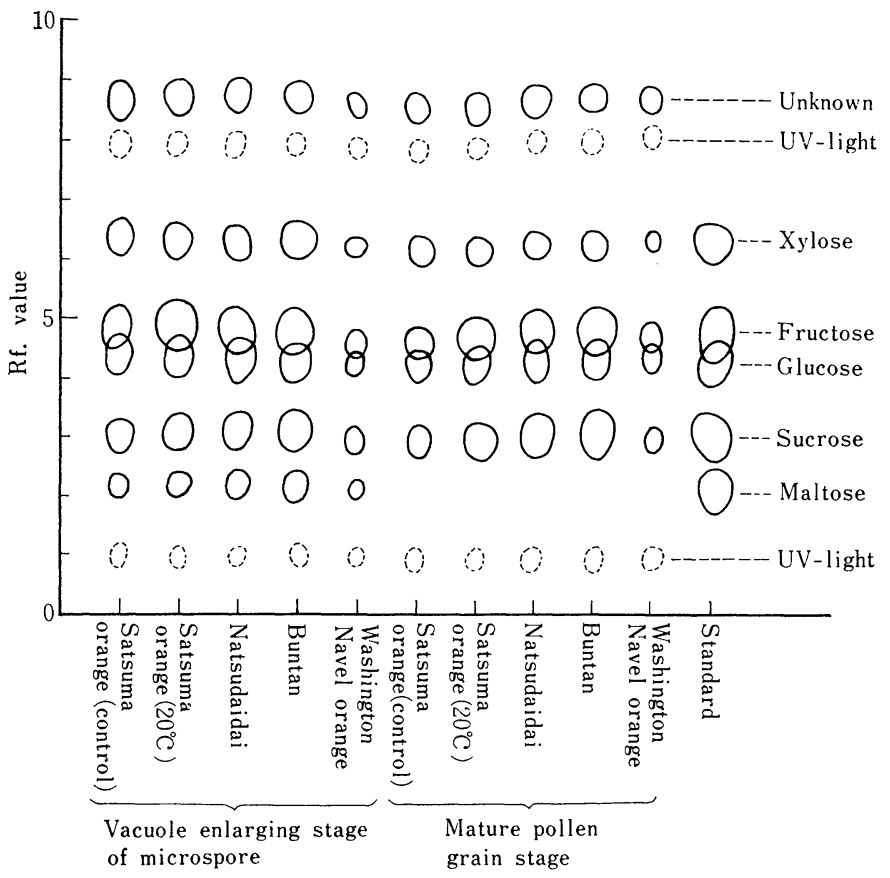

Fig. 6. Comparison of sugar constituents in anther at the vacuole enlarging stage of microspore and mature pollen grain stage among various Citrus plants. 


\section{Effect of temperature on the con-} stituent of sugars in anther:

No differences of free sugar constituents in anther were observed between temperature treated and outdoor control in Satsuma orange and among various Citrus species, as shown in Fig. 6. Several kinds of free sugars, such as glucose, fructose, sucrose, maltose, xylose, two UV-light spots and one unknown spot were detected from the ethanol extraction of the anther in all the examined plots by means of TLC. However, relatively small spots of all free sugars, especially sucrose, glucose, and fructose on TLC from the anther extraction of male sterile species were observed. Moreover, it was found that the spots of sugars on TLC from the anther extraction of $20^{\circ} \mathrm{C}$ temperature treated Satsuma orange were recovered as large as that of the male fertile species.

5. Effect of temperature on enzyme activities in anther at the vacuole enlarging stage and in microspore at the vacuole disappearing stage :

Accumulation of starch in microspores of Satsuma orange occurred in a few fertile ones at the vacuole disappearing stage but it was lacking in most of the sterile ones. When the trees were treated with high temperature treatments (above $15^{\circ} \mathrm{C}$ ) during the bud growing period starch

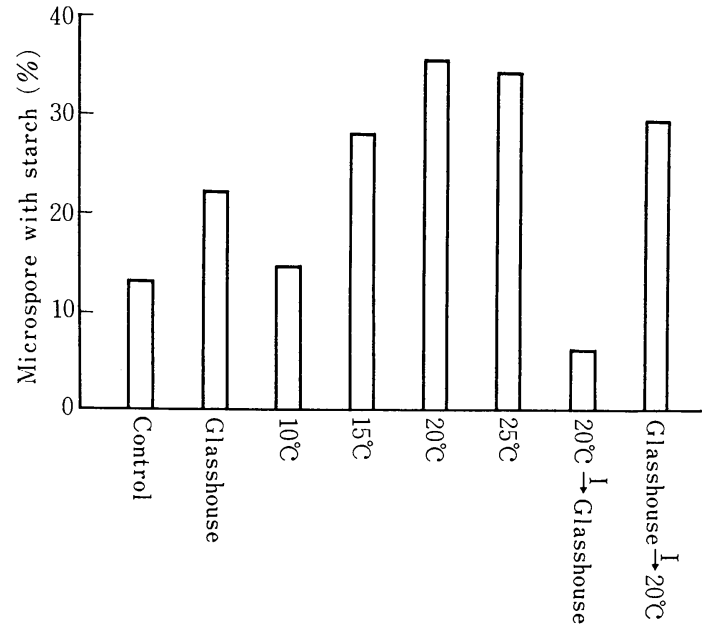

Fig. 7. Percentage of microspores with starch at the vacuole disappearing stage of microspore as affected by the temperature treatments.

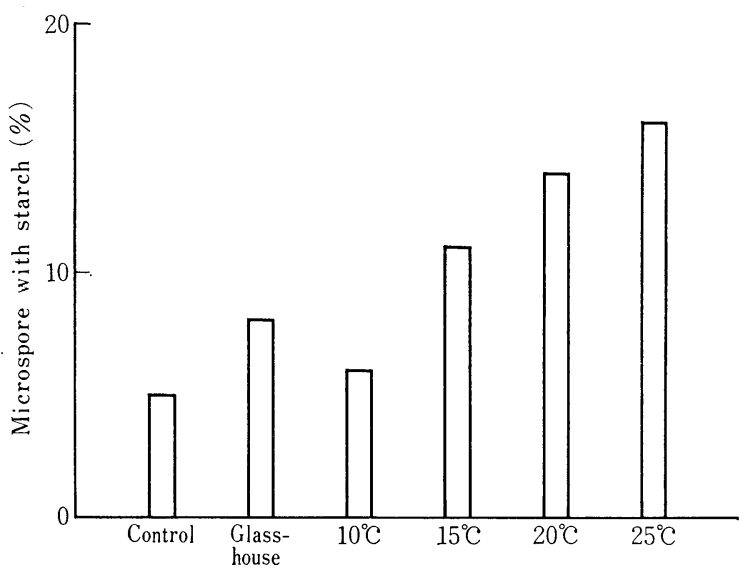

Fig. 8. Activity of starch synthesizing enzyme system in microspores at the vacuole disappearing stage (at $\mathrm{pH} 5.0$ and $37^{\circ} \mathrm{C}$ ) as affected by the temperature treatment. 〔Activity $=\%$ of microspore with starch (incubated) $-\%$ of microspore with starch (control)

contents in microspores increased (Fig. 7). It is well known that starch accumulation is associated with an activity of starch synthesizing enzyme system. Preliminary experiment showed that the activity of stach synthesizing enzyme system in microspore of Satsuma orange was found at the vacuole disappearing stage, although the activity was not detected at the vacuole enlarging stage. Temperature treatments increased the activity of starch synthesizing enzyme system in microspores as shown in Fig. 8. The activities at $25^{\circ} \mathrm{C}$ and $20^{\circ} \mathrm{C}$ were about $2 \sim 3$ times higher than that under the outdoors and at $10^{\circ} \mathrm{C}$.

Starch accumulation in microspores at the vacuole disappearing stage might be closely related to the various enzyme activities in anther just at the vacuole enlarging stage. Therefore, the 

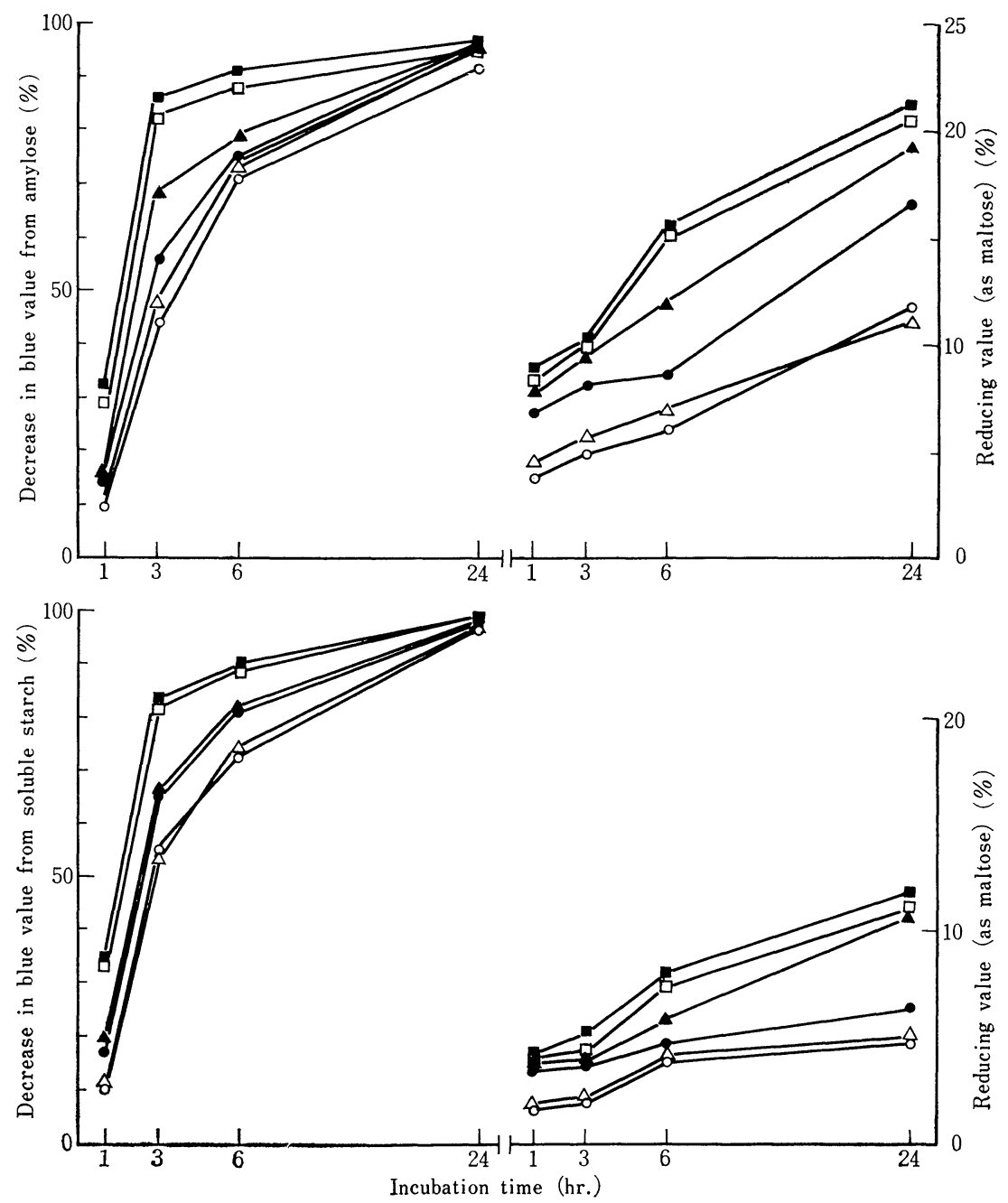

Fig. 9. Amylase activity in anther at the vacuole enlarging stage of microspore (at $\mathrm{pH} 6.5$ and $40^{\circ} \mathrm{C}$ ) as affected by the temperature treatments.
$\bigcirc-\bigcirc$ Control
- Glasshouse
$\triangle-\triangle 10^{\circ} \mathrm{C}$
$\Delta-\Delta 15^{\circ} \mathrm{C}$
$\square-\square \quad 20^{\circ} \mathrm{C}$
- $25^{\circ} \mathrm{C}$

various enzyme activities, such as amylase, maltase, invertase and hexokinase activities in anther at the vacuole enlarging stage were compared among the various temperature treatments. The results are presented in Figs. 9 12. The increase in activity of amylase was much greater for the high temperature treatments than for the low temperature treatments and the control during 3 to 6 hours after incubation. The rates of diminution in blue value from amylose were the same as that from soluble starch. Whereas the reducing value (as maltose) of amylose was higher than that of soluble starch. Therefore, it may be suggested that both $\alpha$-amylase and $\beta$-amylase are contained in anther of Satsuma orange. Similar tendencies were obtained in the case of maltase and invertase activities between high and low temperature treatments. The activities of maltase and invertase at $25^{\circ} \mathrm{C}$ and $20^{\circ} \mathrm{C}$ were about 2.3 


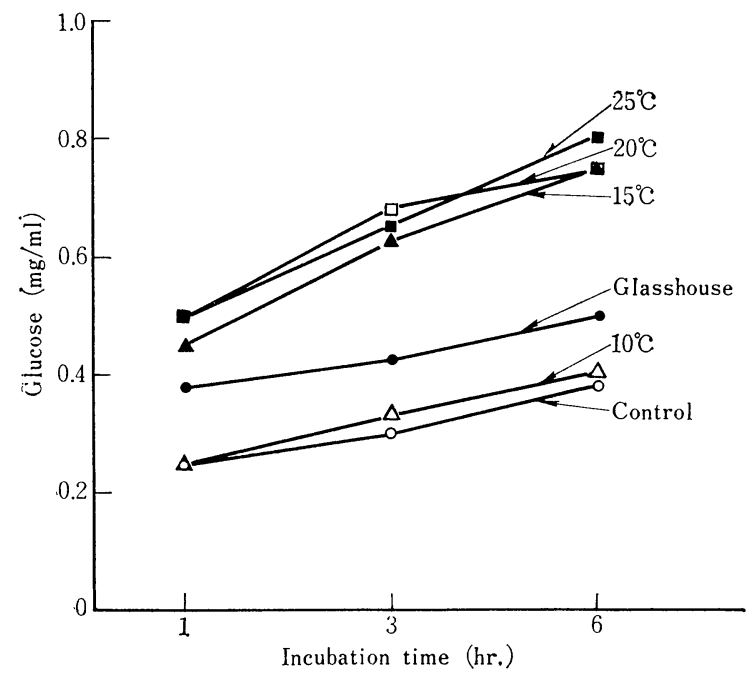

Fig. 10. Maltase activity in anther at the vacuole enlarging stage of microspore (at pH 5.0 and $40^{\circ} \mathrm{C}$ ) as affected by the temperature treatments.

times and 4 times greater respectively than that of the control. The hexokinase activity in anther was expressed as the rate of phosphorylation of glucose and fructose. The rate of phosphory- lation of fructose was greater than that of phosphorylation of glucose. Among the various temp erature treat- ed anther extracts, the rate of phosphorylation of glucose and fructose was the highest at $25^{\circ} \mathrm{C}$, followed by $20^{\circ} \mathrm{C}, 15^{\circ} \mathrm{C}$, glasshouse, $10^{\circ} \mathrm{C}$ and the outdoor control.

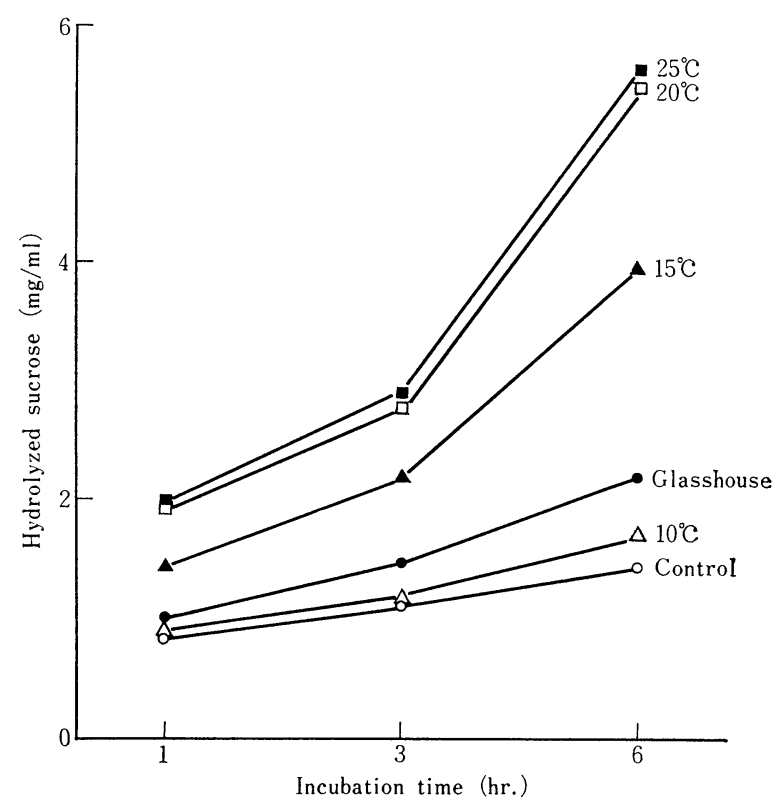

Fig. 11. Invertase activity in anther at the vacuole enlarging stage of microspore (at $\mathrm{pH} 4.0$ and $40^{\circ} \mathrm{C}$ ) as affected by the temperature treatments.

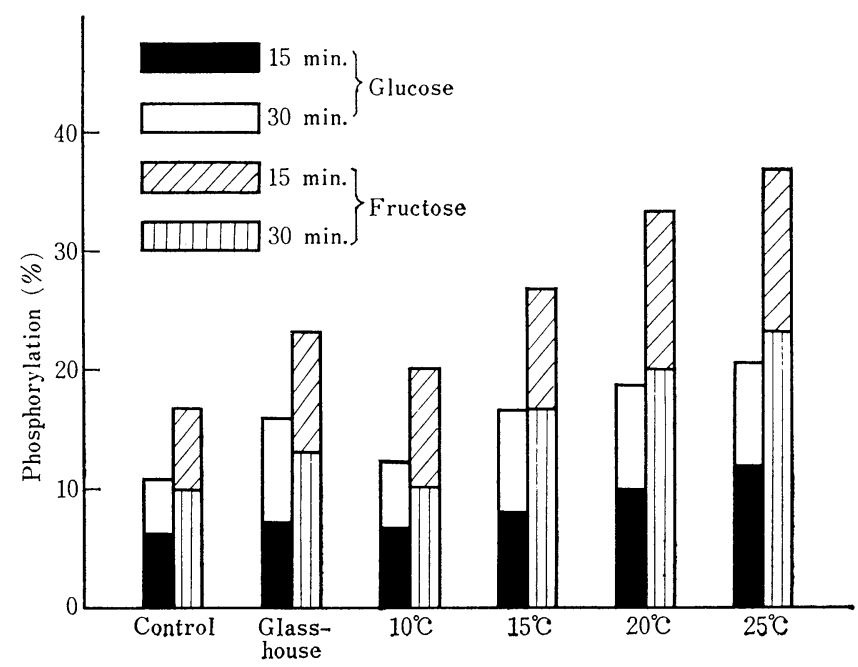

Fig. 12. Hexokinase activity in anther at the vacuole enlarging stage of microspore (at $\mathrm{pH} 7.5$ and $37^{\circ} \mathrm{C}$ ) as affected by the temperature treatments.

\section{Discussion}

The facts that male sterility could be influenced by temperature have been reported in many crops $^{(3,5,9,15,16,17,18,20,25)}$. It has been known in Satsuma orange that the pollen fertility increases under warmer subtropical region of Taiwan, in certain warmer climatic regions of Japan and under glasshouse and the temperature controlled chambers (above $\left.15^{\circ} \mathrm{C}\right)^{(6,8,16,18,30,31)}$.

From the results of the present experiments, the increase in pollen fertility at $20^{\circ} \mathrm{C}, 15^{\circ} \mathrm{C}$ 
and glasshouse $\stackrel{\mathrm{I}}{\longrightarrow} 20^{\circ} \mathrm{C}$ were related to the decrease in the number of large and medium sized abortive pollen grains. On the contrary, the decrease in pollen fertility under $20^{\circ} \mathrm{C} \stackrel{\mathrm{I}}{\longrightarrow}$ glasshouse was also related to the increase in the number of medium sized abortive pollen grains. In the abortive pollen grains, majority of them were medium sized ones and, therefore, it may be considered that the medium sized abortive pollen grains at anthesis were formed during the vacuole disappearing stage of microspore owing to cessation of its growth.

The period of the pollen development from the start of microspore formation to the maturity of pollen under high temperature was shorter than the low temperature. The number of days during the vacuole stage of microspore (from Stage II to Stage IV) was 2 and 4 days at $20^{\circ} \mathrm{C}$ and $15^{\circ} \mathrm{C}$ respectively and 6 days at $10^{\circ} \mathrm{C}$ as well as in the control. In these case, the former showed higher pollen fertility than the latter. Therefore, the number of days during the vacuole stage of microspore might be concerned with the pollen fertility in Satsuma orange.

Cytological observation showed that the abnormalities of meiotic division in PMCs and mitosis in pollens were inconsiderable regardless of the temperature treatments. Moreover, among the temperature treatments the disintegration of cytoplasm in pollen after mitosis stage was at the rate of 15 to $18 \%$. On the other hand, the starch test reaction was negative in most of the microspores during the vacuole disappearing stage which indicated lack of starch. This may be suggested that the microspores would be disturbed their development during the vacuole enlarging stage, and the critical period of the degeneration of pollens would be the vacuole enlarging stage of microspore.

NAKAmURA ${ }^{(18)}$ pointed out that the occurrence of the large vacuole in microspores was a sympton of the deficiency of nutrient, especially carbohydrates. These vacuous starveling microspores could be recovered sufficient energy to absorb carbohydrates and to accumulate an abundant of starch during the vacuole stage, and then developed into the viable pollens, while, the other ones which failed to recover energy and to absorb carbohydrates became abortive. The similar results were observed in many crops by several workers ${ }^{(2,5,7,18,24)}$.

During the vacuole disappearing stage of microspore in Satsuma orange, the starch contents under high temperature condition was much greater than that under low temperature and the outdoor control. $\mathrm{ONO}^{(22)}$ stated that starch forming activity in guard cells of some plants was not recognized at the comparatively lower temperature (below $10^{\circ} \mathrm{C}$ ) and no starch was found in guard cells. Nakamura ${ }^{(18)}$ also reported that the microspores of Citrus ceased to accumulate starch owing to the influence of low temperature. Therefore, the high activity of starch synthesizing enzyme system in microspore under high temperature conditions may be one of the causes for the promotion of the microspore development and then the viable pollen would be produced.

The vacuole disappearance and starch accumulation in microspore at the vacuole disappearing stage might be closely related to the various enzymes activities such as amylase, maltase, invertase and hexokinase in anther just at the vacuole enlarging stage. In the present experiment, the activities of these enzymes in anther at the vacuole enlarging stage under high temperatures were greater than that under low temperatures and the outdoor control. The transformation of glucose from starch and maltose which were reserved in anther walls was 
promoted by high activities of amylase and maltase. Furthermore, the decomposition of sucrose was mediated by invertase and the formation of glucose and fructose could also be promoted. Then, the increased energy was released by the phosphorylations of glucose and fructose which were mediated by hexokinase. Ultimately, the microspore at the vacuole enlarging stage exposed under high temperature might have utilized quickly that rich energy and absorbed nutrient from periphery of the anther sac and excluded the large vacuole from the cytoplasm. Consequently, a large number of microspores under the high temperature conditions recovered and those recovering microspores could enter into the next growth cycle and became the viable pollen grains resulting in an increase of the pollen fertility. While, enzyme activities in anther and microspore at $25^{\circ} \mathrm{C}$ were greater than at $20^{\circ} \mathrm{C}$ temperature treatment. The pollen fertility at $25^{\circ} \mathrm{C}$, however, was less than at $20^{\circ} \mathrm{C}$ temperature treatment. It may be caused by the irregularities of meiotic division in PMCs and mitotic division in pollens and by the disintegration of cytoplasm in pollen grain owing to the high temperature lesion. Furthermore, the nutrient and energy released through the glycolytic pathwa y at $25^{\circ} \mathrm{C}$ in anther were utilized by the rapid growth of anther and were not absorbed by the microspore and pollen during their development. On the contrary, the microspore growing under low temperature conditions and the outdoor control could not obtain enough nutrient and energy to exclude the vacuole from cytoplasm in microspore, and then the empty medium sized pollen grains were produced at anthesis.

\section{Acknowledgments}

The authors wish to express their deepest gratitude to Professor J. Hirai, Department of Horticulture and Agronomy, College of Agriculture, University of Osaka Prefecture, for his valuable guidances throughout the course of this work. The authors are also thankful to Dr. T. Yabuno and Mr. Y. K. Arora for reading the manuscript.

\section{References}

1. AKABORI, S., T. IKenAKA and B. Hagihara. 1956. Amylase. (In Japanese). Kosokenkyuho. II : 108-110. Asakura-Shoten, Tokyo.

2. BRINK, R.A. 1927. The occurrence of self sterility in maize. J. Heredity. $18: 266-269$.

3. Cortessi, H. A. 1967. Investigations made into male sterile beets. Euphytica. 16 : 425432.

4. FROST, H. B. 1948. VIII. Seed reproduction. The Citrus Industry. I : 767-815. Eds. Univ. Calif. Press. Berkeley and LosAngeles.

5. FujishitA, N. 1967. Studies on the mechanism of the pollen degeneration caused by low and high temperature, darkness and gametocide $(\mathrm{FW}-450)$ treatments in vegetable crops. (In Japanese with English summary). Ph. D. thesis. Kyushiu Univ.

6. HORIE, Y. 1918. On the seedlessness of the Satsuma orange. (In Japanese). J. Jap. Hort. Soc. $28: 18-24$.

7. Howllet, F.S. 1936. The effect of carbohydrate and of nitrogen deficiency upon microsporogenesis and the development of the male gametophyte in the tomato (Lycopersicum esculentum MILL). Ann. Bot. 50:767-803.

8. ISHIHARA, S. 1926. Experiments of selfpollination and some consideration of pollination in grapes (In Japanese). J. Okitsu Hort. Soc. $21: 69-76$.

9. IWAHORI, S. 1965. High temperature injuries in tomato. IV. Development of normal flower buds and morphological abnormalities of flower bud treated with high temperature. J. Jap. Soc. Hort. Sci. 34 : 33-41.

10. IWAMASA, M. and T. IWASAKI. 1963. On the sterility phenomenon caused by low temperatures in the Mexican Lime (Citrus aurantifolia). (In Japanese with English summary). Bull. Hort. Res. Sta. Jap. Ser. B. 2 : 25-45.

11. Katsumata, T. and Y. Togasawa. $1968 \mathrm{a}$. Biochemical studies on pollen. IX. The enzymes related to the metabolism of carbohydrates in pollen. (1) On amylase of pollen. (In Japanese with English summary). J. Agr. 
Chem. Soc. Jap. $42: 1-7$.

12. zymes related to the metabolism of carbohydrates in pollen. (2) On invertase and maltase of pollen. (In Japanese with English summary). Ibid. $42: 8-12$.

13. $1968 \mathrm{c}$. XI. The enzymes related to the metabolism of carbohydrates in pollen. (3) On phosphorylase and hexokinase of pollen. (In Japanese with English summary). Ibid. $42: 13-17$.

14. LANGRIDGE, J. 1963. The biochemical aspects of temperature response. Ann. Rev. Plant Physiol. 14 : 441-462.

15. MARREWIJK, G.A.M. van. 1969. cytoplasmic male sterility in Petunia. I. Restoration of fertility with special reference to the influence of environment. Euphytica. $18: 1-20$.

16. NAKAmURA, M. 1934. Cytological studies in the genus Citrus. II. Chromosome number, pollen sterility and the formation of abnormal pollen tetrads. Studia Citrologica. 6:162178.

17. 1936. Experimental and cytological studies of the unstability of the meiotic division of the pollen mother-cells of Impatiens balsamina LinN., caused by the effect of high air temperature. Mem. Fac. Sci. Agr. Taihoku Imp. Univ. $17: 121-184$.

18. 1943. Cytological and ecological studies on the genus Citrus, with special reference to the occurrence of sterile pollen grain. Ibid. $27: 53-159$.

19. NELSON, N. 1944. A photometric adaption of the Somogyi method for the determination of glucose. J. Biol. Chem. 153 : 375-380.

20. NIEUWHOF, M. 1968. Effect of temperature on the expression of male sterility in brussels sprouts (Brassica oleracea L. var. gemmifera DC.) Euphytica. $17: 265-273$.
21. Noelting, G. and P. Bernfeld. - 1948. Sur les enzymes amylolytiques. III. La $\beta$-amylase: dosage d'activite et contrôle de l'absence d' $\alpha$ amylase. Helv. Chim. Acta. $31: 286-290$.

22. ONO, H. 1953. On the mechanism of the formation of starch in plants. I. Especially in guard cells. (In Japanese with English summary). Bot. Mag. Tokyo $66: 103-111$.

33. ROE, J. H., J. H. EPSTEIN and N. P. GoldSTEIN. 1949. A photometric method for the determination of inulin in plasma and urine. $\mathrm{J}$. Biol. Chem. $178: 839-845$.

24. RUdloff, C. F. and M. SchmidT. 1932. Einfluss ungünstiger witterungsverhältniss auf Reduktionsteilung und Embryosackentwicklung bei Oenotheren. Planta. 18 : 104-167.

25. SAKAI, K. 1949. Cyto-histological and genetical studies on the sterility of rice plants as influenced by low temperature with special reference to the hypertrophy of tapetum. (In Japanese). Bull. Hokkaido Agr. Exp. Sta. $43: 1-46$.

26. Somogyi, M. 1952. Notes on sugar determination. J. Biol. Chem. $195: 19-23$.

27. STocking, C. R. 1952. The intracellular location of phosphorylase in leaves. Amer. J. Bot. $39: 283-287$.

28. STUMPF, P. K. 1952. Glycolytic enzymes in high plants. Ann. Rev. Plant Physiol. 3 : $17-34$.

29. YANG, H. J. and S. NAKAGAWA. 1969a. The critical period of degeneration of tapetum and pollen grains in Satsuma orange (Citrus unshiu MARC.). J. Jap. Soc. Hort. Sci. 38 : 137-143.

30. $\longrightarrow$ and 1969b. Cyto-histological studies on the male sterility of Satsuma orange (Citrus unshiu MARC.). J. Jap. Soc. Hort. Sci. 38 : 239-245.

31. Umikita, M. 1912. On the parthenocarpy in Citrus. J. Jap. Hort. Soc. 24(11) : 1-9. 
温州ミカンの雄性不稔に関する研究

花粉稔性の回復に関係する䒬内の炭水化物の代謝

おょび酵素活性に及ぼす温度の影響

楊緒壬・中川昌一

(大阪府立大学農学部)

$\longrightarrow$

摘 要

温州ミカンの花粉稔性は, その発達過程に打ける温度 条件によつて差異があり, 温暖条件のもとでは花粉稔性 が高められることが知られている。本研究は温州ミカン の鉢植 $5 \sim 6$ 年生樹を用い, ガラス室内に設けたビニル ハウス内に入れ，その最低温度を $10^{\circ} \mathrm{C}, 15^{\circ} \mathrm{C}, 20^{\circ} \mathrm{C}$ お よび $25^{\circ} \mathrm{C}$ に調節し, 花蕾の発育期間中買なる温度条件 において, 小胞子および花粉の発達と退化の様相を調査 するとともに, 䓎内の炭水化物の代謝および醳素活性に ついて実験を行なつた。

温度処理した温州ミカンの花粉稳性を露地に比べる と, 花粉稔性の上昇率は $15^{\circ} \mathrm{C}$ 処理区では $14 \%, 20^{\circ} \mathrm{C} て ゙$

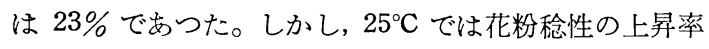
はわずか $6 \%$ であり, また花蕾は小さく, 弱々しい外観 を示し, 開花後 $2 \sim 3$ 週間以内に子房や, 幼果が全部離脱 した。したがつて温州ミカンの稌性を上昇させる温度条 件は花粉稔性の上昇率と花蕾の 発育の両方を考慮すれ ば, 花蕾から開花までの期間中, 最低温度 $15 \sim 20^{\circ} \mathrm{C}$ が
適当であると考えられた。

温度処理によつて稔性花粉が増加することは, 加温に よつて液胞期およびそれ以後の花粉の発達が進行し, デ ンプンを集積した小胞子の数が增大するためである。高 温下で竹内のアミラーゼ, マルターゼ, インベルターゼ, ヘキソキナーゼおよび小胞子内のデンプン合成酵素系の 活性を測定した結果それが高まつていたことから, 葯壁 に貯蔵されていたデンプンが多量に分解され，小胞子に 十分な栄裳を供給できるようになる。また䒺内の解糖経 路からも多量のエネルギーが放出されることが考えられ る。この結果, 液胞をむつた飢餓状態の小胞子はタペー ト細胞などを含を葯壁から栄養分を吸収して, 細胞質内 の液胞を排除し, 液胞期およびそれ以後の発育過程を円 滑に進め, 液胞を消失するとともに, 栄養物質としてデ ンプンを十分に集積して稔性花粉となり, 花粉稔性を高 めたものと考えられる。 